GRASAS Y ACEITES 66 (4)

October-December 2015, e098

ISSN-L: 0017-3495

doi: http://dx.doi.org/10.3989/gya.1316143

\title{
Kinetics of enzymatic hydrolysis of methyl ricinoleate
}

\author{
T.S.V.R. Neeharika ${ }^{\mathrm{a}}$, P. Lokesh ${ }^{\mathrm{a}}$, K.N. Prasanna Rani ${ }^{\mathrm{a},}$, T. Prathap Kumar ${ }^{\mathrm{b}}$ and R.B.N. Prasad ${ }^{\mathrm{a}}$ \\ ${ }^{\mathrm{a}}$ Centre for Lipid Research, ${ }^{\mathrm{b}}$ Chemical Engineering Division, CSIR-Indian Institute of Chemical Technology, Hyderabad - 500007 \\ ${ }^{\square}$ Corresponding author: knpr@iict.res.in
}

Submitted: 29 December 2014; Accepted: 21 April 2015

SUMMARY: Ricinoleic acid is an unsaturated hydroxy fatty acid that naturally occurs in castor oil in proportions of up to $85-90 \%$. Ricinoleic acid is a potential raw material and finds several applications in coatings, lubricant formulations and pharmaceutical areas. Enzymatic hydrolysis of castor oil is preferred over conventional hydrolysis for the preparation of ricinoleic acid to avoid estolide formation. A kinetics analysis of the enzymatic hydrolysis of Methyl Ricinoleate in the presence of Candida antarctica Lipase B was carried out in this study by varying reaction temperature $\left(40-60{ }^{\circ} \mathrm{C}\right)$ and enzyme concentration $(2-5 \%)$. The optimal conditions were found to be $6 \mathrm{~h}$ reaction time, temperature $60^{\circ} \mathrm{C}$, buffer to methyl ricinoleate ratio $2: 1(\mathrm{v} / \mathrm{w})$ and $4 \%$ enzyme concentration to achieve a maximum conversion of $98.5 \%$. A first order reversible reaction kinetic model was proposed to describe this reaction and a good agreement was observed between the experimental data and the model values. The effect of temperature on the forward reaction rate constant was determined by fitting data to the Arrhenius equation. The activation energy for forward reaction was found to be $14.69 \mathrm{KJ} \cdot \mathrm{mol}^{-1}$.

\section{KEYWORDS: Hydrolysis; Kinetics; Methyl ricinoleate; Ricinoleic acid}

RESUMEN: Cinética de la hidrólisis enzimática del ricinoleato de metilo. El ácido ricinoleico es un hidroxi ácido insaturado que se produce naturalmente en el aceite de ricino en proporciones de hasta el $85-90 \%$. El ácido ricinoleico es una materia prima con gran potencial y tiene aplicaciones en revestimientos, formulaciones lubricantes y en áreas farmacéuticas. Para la preparación del ácido ricinoleico se prefiere la hidrólisis enzimática del aceite de ricino a la hidrólisis convencional, para evitar la formación de estólidos. En este estudio se llevó a cabo la cinética de la hidrólisis enzimática del ricinoleato de metilo en presencia de lipasa de Candida antarctica B mediante la variación de la temperatura de reacción $\left(40-60{ }^{\circ} \mathrm{C}\right)$ y la concentración de la enzima $(2-5 \%)$. Las condiciones óptimas de la reacción para alcanzar una conversión máxima de 98,5\% fueron: 6 h de reacción, $60{ }^{\circ} \mathrm{C}$, relación tampón/ ricinoleato de metilo: $2: 1$ (v/w) y una concentración de enzima del 4\%. Se propone un modelo cinético de reacción reversible de primer orden para describir esta reacción y se observó una buena concordancia entre los datos experimentales y los valores del modelo. El efecto de la temperatura sobre la constante de velocidad de la evolución de la reacción se determinó mediante su incorporación a la ecuación de Arrhenius. La energía de activación para el progreso de la reacción se encontró que era de $14.69 \mathrm{KJ} \cdot \mathrm{mol}^{-1}$.

PALABRAS CLAVE: Ácido ricinoleico; Cinética; Hidrólisis; Metil ricinoleato

Citation/Cómo citar este artículo: Neeharika TSVR, Lokesh P, Prasanna Rani KN, Prathap Kumar T, Prasad RBN 2015. Kinetics of enzymatic hydrolysis of methyl ricinoleate. Grasas Aceites 66 (4): e098. doi: http://dx.doi.org/10.3989/ gya. 1316143

Copyright: (c) 2015 CSIC. This is an open-access article distributed under the terms of the Creative Commons Attribution-Non Commercial (by-nc) Spain 3.0 Licence. 


\section{INTRODUCTION}

Global castor seed production is around one million tons per year and India is the major producer and exporter of castor oil (with over three-quarters of the global yield). The seed production is estimated to be over 8,30,000 tons per year on average. Castor oil is the only commercial source of unsaturated hydroxyl acid (12-hydroxy-cis-9-octadecenoic acid), which is ricinoleic acid to the extent of $85-90 \%$ and is the feedstock for many of the useful industrial chemicals. Ricinoleic acid has 18 carbons on its backbone with one hydroxyl group on the $12^{\text {th }}$ carbon atom and it also has a cis double bond between the $9^{\text {th }}$ and $10^{\text {th }}$ carbon atoms. Castor oil is mostly used in the form of its modified derivatives such as dehydrated, hydrogenated, alkoxylated, sulphated and the halogenated derivatives (Patel et al., 2004). Castor oil is also used in a wide range of cosmetics, toiletries, transparent soaps and in lubricating formulations. Many of the industrial castor-based chemicals are made either with castor oil/castor fatty acids or mostly its methyl esters as such, containing $85-90 \%$ ricinoleic content.

Generally methyl ricinoleate is obtained by alcoholysis of castor oil, followed by fractional distillation of the crude esters and further purification by low temperature crystallization. Berdeaux et al. (1997) isolated methyl ricinoleate from castor oil methyl esters by countercurrent distribution using hexane and aq. methanol to give $98.5 \%$ pure methyl ricinoleate with $86.5 \%$ yield. This process seems quite tedious as extraction was carried out 12 times.

An enriched ricinoleic content with more hydroxyl value is an added advantage in the preparation of many useful industrial products with enhanced desired properties. The major advantage of this process is that methyl ricinoleate (Rao et al., 2009) upon hydrolysis yields ricinoleic acid with less impurities and can be a potential candidate as a raw material for different industrial applications. When methyl ricinoleate is used as a raw material for the preparation of potential industrial products the end products will have much less impurities because the feed material is of the highest purity, whereas using castor oil as starting material has a few disadvantages such as the formation of estolides and the fact that the purification of ricnoleic acid is a tedious process. Therefore, in order to overcome these limitations, this study is focused on using methyl ricinoleate for the preparation of ricinoleic acid. This is a simple process where we have no impurities.

Previous investigations reveal a meagre study on the hydrolysis of castor oil methyl esters or methyl ricinoleate for the preparation of ricinoleic acid; the literature shows data on the hydrolysis of castor oil using different enzymes. Rathod and Pandit (2009) studied the hydrolysis of castor oil using Aspergillus oryzae, at room temperature with a 3:1 oil to water ratio. Kulkarni and Pandit (2005) also used the same enzyme, but adopted a different contacting pattern for enzyme interaction by suspending the enzyme in isooctane at different time intervals and then determining the residual activity. The authors claimed that the rate of reaction was considerably improved by the addition of a solvent. Goswami et al. (2013) reviewed triacylglycerol acylhydrolase lipase for the hydrolysis of vegetable oil and studied castor oil in particular. They statistically showed that interactions between any two parameters involving $\mathrm{pH}$, enzyme concentration and buffer concentration become significant in the presence of a nonionic surfactant named Span 80. Also Goswami et al. (2009a) applied response surface methodology for the hydrolysis of castor oil using Candida rugosa lipase.

Yamamoto and Fujiwaran (1995) examined the optimal hydrolytic conditions for the hydrolysis of castor oil using the lipase from Pseudomonas sp. f-B-24 (lipase PC) and reported the apparent $\mathrm{K}_{\mathrm{m}}$ and $\mathrm{V}_{\max }$ for the system as 416 g.L $\mathrm{L}^{-1}$ and $110 \mu \mathrm{mol} \cdot \mathrm{mg}^{-1} \cdot \mathrm{min}^{-1}$ respectively. Rao et al. (1990) studied lipolysed castor oil in situ using homogenized castor seed at small scale and large scale (Rao and Paulose 1992). Goswami et al. (2009b) examined the reusability of lipase for the hydrolysis of castor oil in the presence of Candida rugosa lipase.

Lakshminarayana et al. (1984) used a conventional high pressure splitting process for the hydrolysis of castor oil. They reported a $92 \%$ split in $8 \mathrm{~h}$ and $96 \%$ in $10 \mathrm{~h}$ at $40 \mathrm{~kg} \cdot \mathrm{cm}^{-2}$ and $20 \mathrm{~kg} \cdot \mathrm{cm}^{-2}$. They claimed that splitting at $20 \mathrm{~kg} \cdot \mathrm{cm}^{-2}$ gave minimal amounts of dienoic acids. Puthli et al. (2006) investigated various parameters such as time, reusability of enzymes, non-aqueous phase ratio, effects on interfacial area and effect of enzyme dosing for the hydrolysis of castor oil.

Sharon et al. (1999) used a highly stable lipase from Pseudomonas aeruginosa for hydrolyzing castor oil with $300 \mathrm{U}$ crude and partially-purified lipase. Partially purified lipase hydrolyzed $81 \%$ castor oil within a period of $96 \mathrm{~h}$ where as crude lipase hydrolyzed only $63 \%$ castor oil in $216 \mathrm{~h}$. Three different lipases such are Porcein pancrease, Candida cylindracea, and Candida rugosa were tested for the hydrolysis of castor oil by Yang et al. (1999) for the mass production of ricinoleic acid. Gamayurova et al. (2013) proposed a method for hydrolysis without emulsifiers, simplifying the process of isolating the product, but with a lower yield of $47 \%$. Neeharika et al. (2014) applied an experimental design for the hydrolysis of enriched castor oil methyl esters.

Generally ricinoleic acid is obtained from castor oil through hydrolysis, usually carried out under basic conditions and further purified. Industrially, ricinoleic acid is manufactured by saponification or fractional distillation of hydrolyzed castor oil. 
This study provides an alternative and simple enzymatic method for the production of ricinoleic acid with high purity through the hydrolysis of methyl ricinoleate. In addition, this study determines the kinetics for the enzymatic hydrolysis of methyl ricinoleate with a view to examine the influence of operation variables like reaction time, enzyme concentration and temperature using Candida antarctica lipase B as a catalyst.

\section{MATERIALS AND METHODS}

\subsection{Materials}

The methyl ricinoleate used in the experiments was $100 \%$ pure with a hydroxyl value of 172.1 , and saponification value of 167.1. Immobilized Candida antarctica lipase B (Novozym 435, specific activity $7000 \mathrm{PLU} / \mathrm{g}$ ) was provided by Novozymes A/S (Bagsvaerd, Denmark). All the chemicals such as methanol, ethyl acetate, potassium hydroxide, and phenolphthalein indicator, were of analytical grade procured from M/s. Sd Fine Chem. Pvt. Ltd., Mumbai. A phosphate buffer of $7.5 \mathrm{pH}$ was prepared in the laboratory.

\subsection{Methods}

The fatty acid composition of methyl ricinoleate was analyzed using a Gas Chromatograph Agilent 6890 series equipped with a flame ionization detector in accordance with the AOCS official method Ce 1e-91. The stationary phase used was a capillary column, HP1 MS (i.d. $0.25 \mathrm{~mm}$, length $30 \mathrm{~m}$ ). The oven temperature was programmed from 150 to $300{ }^{\circ} \mathrm{C}$ at $5^{\circ} \mathrm{C}$ per minute with nitrogen at a flow rate of $35 \mathrm{~mL} \cdot \mathrm{min}^{-1}$. The injector and detector temperatures were maintained at 280 and $300^{\circ} \mathrm{C}$, respectively. The area percentage was recorded using an HP Chem Station Data System. The methyl ricinoleate was found to be $100 \%$ pure. Acid value and saponification value were determined as per AOCS official methods Cd 3d-63 and Cd 3-25 (AOCS 2004a and AOCS 2004b).

\section{Method for Preparation of Methyl Ricinoleate:}

The enrichment of castor oil methyl esters was carried out according to the procedure explained by Rao et al., 2009. Castor oil was subjected to transesterification using methanol and $\mathrm{NaOH}$ and later the obtained castor oil methyl esters were subjected to liquid liquid extraction by combining with an organic medium and an aqueous polar solvent. This results in both aqueous and organic layers. The aqueous layer is the source for enriched castor oil methyl esters and the organic layer contains non-hydroxy fatty acids. The methyl ricinoleate obtained by desolventizing the aqueous polar phase was found to be $100 \%$ pure.

\subsection{Experimental Procedure}

Methyl ricinoleate was hydrolyzed using Candida antarctica lipase in the presence of required amounts of phosphate buffer $(2: 1)(\mathrm{v} / \mathrm{w})$. The reaction mixture was incubated for $6 \mathrm{~h}$ at $60{ }^{\circ} \mathrm{C}$. Samples were drawn at regular intervals of time to monitor the progress of the reaction. Samples were filtered, neutralized with water, dried and analyzed. The ricinoleic acid in the product was estimated by the determination of the acid value. $0.5 \mathrm{~g}$ of ricinoleic acid obtained by enzymatic hydrolysis were subjected to titration against a $0.1 \mathrm{~N} \mathrm{KOH}$ solution and its acid value was estimated and was used for calculating the hydrolysis percentage.

The percentage hydrolysis was calculated using the following formula:

$\%$ Hydrolysis $=\frac{A V \text { of product }- \text { AV of Methyl Ricinoleate }}{\text { SV of Methy Ricinoleate }} \times 100$

Where $A V$ is the acid value and $S V$ is the saponification value

Different sets of experiments were carried out using different operating conditions to arrive at optimum process conditions. The first set of experiments were carried out by varying time from $30 \mathrm{~min}$ to $6 \mathrm{~h}$, while maintaining the other reaction parameters constant i.e., 4\% enzyme concentration, buffer to methyl ricinoleate ratio 2:1 (v/w) and temperature $60^{\circ} \mathrm{C}$. A second set of experiments was carried out at temperatures ranging from 40 to $60{ }^{\circ} \mathrm{C}$, while maintaining other reaction parameters constant i.e., $4 \%$ enzyme concentration, buffer to methyl ricinoleate ratio 2:1 (v/w), time period of $6 \mathrm{~h}$. The third set of experiments was carried out at enzyme concentrations ranging from 2 to $5 \%$ by keeping a fixed buffer to methyl ricinoleate ratio of $2: 1(\mathrm{v} / \mathrm{w})$ and $60{ }^{\circ} \mathrm{C}$.

\subsection{Statistical analysis}

The experiments were carried out in duplicate for experimental error estimation and the data was analyzed by a paired Student's t-test to evaluate the level of statistical significance. A p-value of less than 0.05 was considered significant. A p-value of 0.04896 was obtained which was considered as significant.

\subsection{Kinetic Model}

For the present reaction system, one substrate first-order reversible model was considered (Knezevic et al. 1998). The reaction mechanism for the kinetic model involving the reversible reaction is as follows:

$A+B \underset{k_{2}}{\stackrel{k_{1}}{\Leftrightarrow}} C+D$

The reaction rate equation is expressed as:

$r_{A}=-\frac{d C_{A}}{d t}=k_{1} C_{A}-k_{2} C_{C} C_{D}$

Eq. 2 
where $C_{A}, C_{C}$ and $C_{D}$ denote the concentration of methyl ricinoleate, concentration of ricinoleic acid and the concentration of methanol formed during the reaction, respectively. $C_{B}$ is the amount of water which was not considered for developing the kinetic model. $k_{1}$ and $k_{2}$ are kinetic rate constants for the forward and backward reactions, respectively.

As $C_{A}=C_{A_{0}}\left(1-X_{A}\right)$ (where $X_{A}$ is the conversion of methyl ricinoleate and $C_{A_{0}}$ is the initial concentration of methyl ricinoleate), and $C_{C}=C_{D}=C_{A_{0}}-C_{A}=C_{A_{0}} X_{A}$, substituting these in Eq. 2, and simplifying we get:

$\frac{d X_{A}}{d t}=k_{1}\left(1-X_{A}\right)-k_{2} C_{A_{0}} X_{A}^{2}$ At equilibrium, $\frac{d X_{A}}{d t}=0$ and $X_{A}=X_{E}$, and from Eq. 3,
we get:

$k_{2}=\frac{k_{1}\left(1-X_{E}\right)}{C_{A_{0}} X_{E}^{2}}$

By substituting the value of $k_{2}$ in Eq. 3 and rearranging the terms, we get:

$\frac{d X_{A}}{d t}=\frac{k_{1}}{X_{E}^{2}}\left[\left(X_{E}-1\right) X_{A}^{2}-X_{E}^{2} X_{A}+X_{E}^{2}\right]$

Integration of Eq. 5 yields

$\ln \left[\frac{X_{A}-X_{E}}{X_{A}\left(X_{E}-1\right)-X_{E}}\right]=\frac{\left(X_{E}-2\right)}{X_{E}} k_{1} t$

Eq. 6

The conversion as a function of time can be deduced from Eq. 6 as follows:

$X_{A}=\frac{X_{E}\left(1-e^{\beta t}\right)}{\left[1-X_{E} e^{\beta t}+e^{\beta t}\right]}$

Where $\beta=k_{1} \frac{\left(X_{\mathrm{E}}-2\right)}{X_{\mathrm{E}}}$

Rearranging the terms gives rate constant

$k_{1}=\frac{\beta X_{E}}{\left(X_{E}-2\right)}$

Eq. 8

\section{RESULTS AND DISCUSSION}

Optimization of the hydrolysis of methyl ricinoleate was carried out using Candida antarctica lipase by studying the effect of various parameters such as time, temperature, and enzyme concentration.

\subsection{Effect of Reaction Time}

The rate of hydrolysis of the reaction depends on reaction time. Reaction time was optimized by conducting experiments at an enzyme concentration of $4 \%, 60{ }^{\circ} \mathrm{C}$, buffer to methyl ricinoleate ratio of $2: 1$ $(\mathrm{v} / \mathrm{w})$. Figure 1 shows a linear plot as a function of

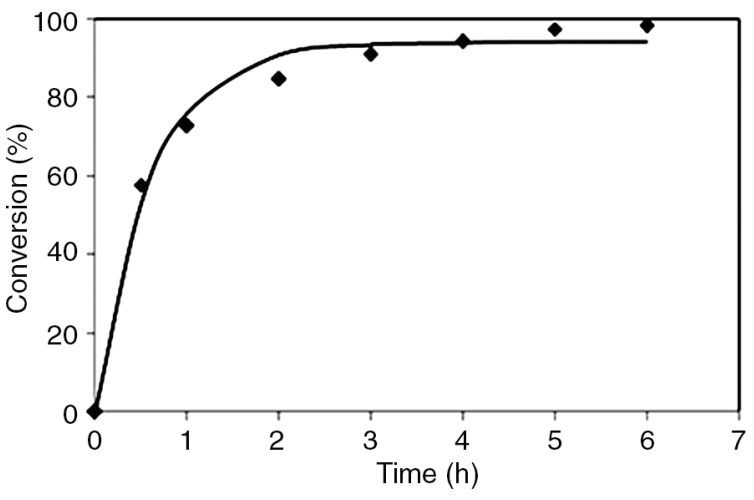

FiguRE 1. Effect of time of reaction on hydrolysis of methyl ricinoleate.

(Reaction temperature $60{ }^{\circ} \mathrm{C}$, enzyme concentration $4 \%$, buffer to methyl ricinoleate ratio of $2: 1(\mathrm{v} / \mathrm{w}))$

- experimental values — model values.

reaction time and conversion. It is apparent from the figure that reaction proceeds faster during the initial $30 \mathrm{~min}$. It is apparent from the figure that conversion increased as the reaction time increased. The most desirable reaction period for the hydrolysis of methyl ricinoleate was found to be $6 \mathrm{~h}$.

\subsection{Effect of Reaction Temperature}

The temperature profiles of hydrolysis reaction at $4 \%$ enzyme concentration, buffer to methyl ricinoleate ratio of 2:1 (v/w) and $6 \mathrm{~h}$ reaction time is shown in Figure 2. It can be inferred from the plot that the reactant conversion increased as the temperature increased. At $40{ }^{\circ} \mathrm{C}$, the conversion was $81.1 \%$ and by increasing the temperature to $50{ }^{\circ} \mathrm{C}$, conversion reached $90.5 \%$ and at $60^{\circ} \mathrm{C}$, a maximum conversion of $98.5 \%$ was obtained. A further increase in temperature to $70^{\circ} \mathrm{C}$ decreased the conversion to $87.9 \%$.

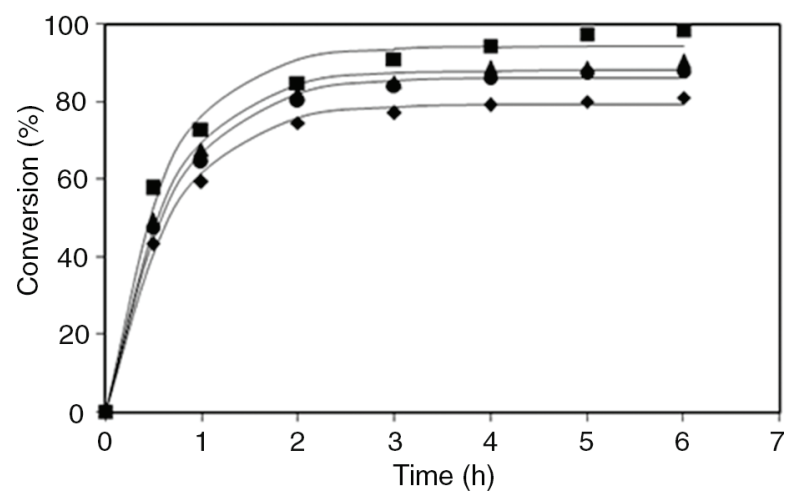

FIGURE 2. Effect of reaction temperature on hydrolysis of methyl ricinoleate.

(Reaction time $6 \mathrm{~h}$, enzyme concentration 4\%,

buffer to methyl ricinoleate ratio of $2: 1(\mathrm{v} / \mathrm{w})$ )

• $40^{\circ} \mathrm{C} \triangle 50{ }^{\circ} \mathrm{C} \square 60{ }^{\circ} \mathrm{C} \bullet 70^{\circ} \mathrm{C}$ model values. 
The temperature was not increased beyond this limit as enzymes get deactivated at higher temperatures.

\subsection{Effect of Enzyme Concentration}

Generally, lipase catalyzed reactions take place at the interface, and the amount of enzyme available at the interface is very important. To determine the effect of enzyme amount on the hydrolysis reaction, we investigated different enzyme dosages for the reaction from 2 to $5 \%$ with buffer to methyl ricinoleate ratio $2: 1(\mathrm{v} / \mathrm{w})$ at $60{ }^{\circ} \mathrm{C}$ for $6 \mathrm{~h}$. Fig. 3 represents the effect of enzyme concentration on conversion. It is inevitable that as the enzyme concentration increased from 2 to $5 \%$, conversion increased as a greater amount of enzyme was available for the reaction. When the enzyme concentration was $2 \%$ the conversion was $86.5 \%$, at $4 \%$ enzyme dosage, conversion was $98.5 \%$. A further increase in enzyme concentration to $5 \%$ did not yield any further increase in conversion. Hence this value was considered as optimum for this parameter.

\subsection{Applying the Kinetic model}

The derived kinetic model for one substrate first order reversible reaction was fitted to the experimental data and the two parameters, $X_{E}$ and $\beta$ of Eq. 7 were determined by non-linear regression with a Levenberg-Marquardt algorithm using statistical software. A regression co-efficient value of 0.98 indicates that the model is statistically significant and adequate to represent the relationship between the experimental and theoretical parameters. The rate constants for the forward reaction, $k_{1}$ and backward reaction, $k_{2}$ was calculated from Eq. 8 and Eq. 4, respectively. The results obtained for rate constants, $k_{1}$ and $k_{2}$, and the equilibrium conversion $\mathrm{K}$ are reported in Table 1.

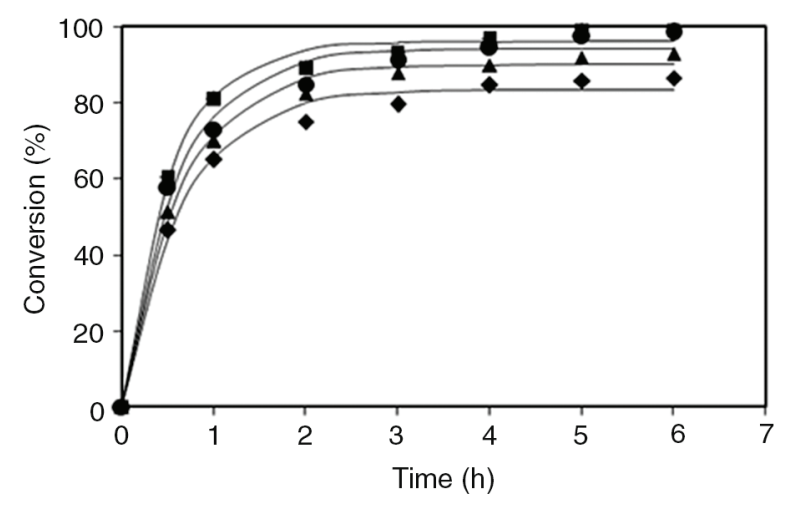

FIGURE 3. Effect of enzyme concentration hydrolysis of methyl ricinoleate.

(Reaction time $6 \mathrm{~h}$, buffer to methyl ricinoleate ratio of 2:1 (v/w), temperature $\left.60{ }^{\circ} \mathrm{C}\right) \bullet 2 \% \Delta 3 \% \bullet 4 \% \square 5 \%$ model values
TABLE 1. Equilibrium conversion, kinetic rate constants and equilibrium constant for the hydrolysis of methyl ricinoleate at different reaction temperatures

\begin{tabular}{lcccc}
\hline Temperature $\left({ }^{\circ} \mathbf{C}\right)$ & $\mathbf{X}_{\mathbf{e}}$ & $\mathbf{k}_{\mathbf{1}}$ & $\mathbf{k}_{\mathbf{2}}$ & $\mathbf{K}$ \\
\hline 40 & 0.79285 & 1.077649 & 221.9455 & 0.004855 \\
50 & 0.88082 & 1.291866 & 124.026 & 0.010416 \\
60 & 0.94243 & 1.512378 & 61.2667 & 0.024685 \\
70 & 0.86291 & 1.203175 & 138.4426 & 0.008691 \\
\hline
\end{tabular}

The effect of temperature on the forward reaction rate constant was obtained by fitting $k_{1}$ to the following Arrhenius equation (Eq. 9 and Eq. 10).

$k=A e^{\left[\frac{-\Delta E}{R T}\right]}$

and

$\ln k_{1}=\frac{-\Delta E}{R T}+\ln A$

The rate constant, $k_{1}$, for the forward reaction is calculated using Eq. 8. From the plot of $\ln k_{1}$ as a function of the reciprocal temperature, as shown in Figure 4, for 4\% enzyme concentration, the frequency factor, $A$, and the energy of activation, $\Delta E$, were found to be $5.15 \times 10^{4}$ and $27.6 \mathrm{KJ} \cdot \mathrm{mol}^{-1}$, respectively.

The fitting of the experimental data to the proposed model was also assessed by comparing the experimental conversion values with the theoretically predicted conversions using Eq. 6, and is presented in Figure 4. A good agreement between the experimental conversion and the values calculated from Eq. 6 was observed. Since the $p$-value for the model was lower than 0.05 there was a statistical relation between the response and the selected variables at 95\% confidence level. It can be inferred that the proposed model represented the present reaction system satisfactorily.

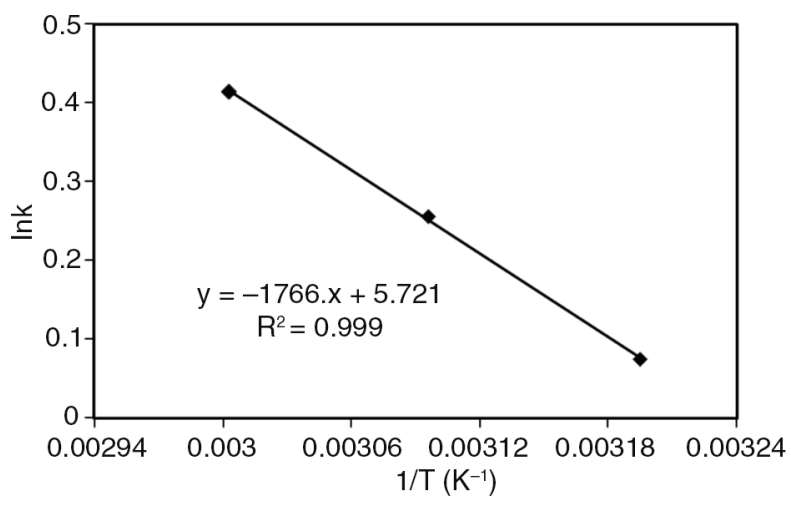

FIGURE 4. Effect of reaction temperature on reaction rate constant. 


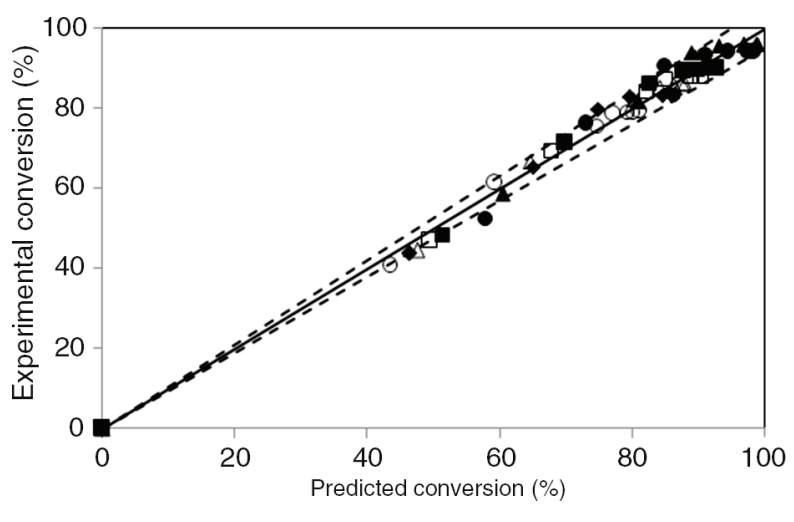

Figure 5. Comparison of experimental and predicted conversions.

• $2 \% \square 3 \% \bullet 4 \% \Delta 5 \% \circ 40^{\circ} \mathrm{C} \square 50{ }^{\circ} \mathrm{C} \Delta 70{ }^{\circ} \mathrm{C}$

\section{CONCLUSIONS}

Methyl ricinoleate can be used as a potential raw material due to its enriched ricinoleic acid content. In this study we have optimized processing conditions like reaction time, enzyme concentration and temperature for achieving maximum yields of ricinoleic acid using Candida antarctica lipase $B$ as a catalyst using response surface methodology. The degree of hydrolysis of methyl ricinoleate was significantly affected by the hydrolysis conditions including reaction time, enzyme concentration, amount of buffer and temperature. A good agreement was observed between the experimental data and the predicted values. The optimized conditions for the hydrolysis of methyl ricinoleate were found to be $4 \%$ enzyme concentration, buffer to methyl ricinoleate ratio $2: 1(\mathrm{v} / \mathrm{w})$ and $60{ }^{\circ} \mathrm{C}$ temperature for $6 \mathrm{~h}$, under optimum conditions a maximum conversion of $98.5 \%$ was obtained.

\section{ACKNOWLEDGMENTS}

The authors greatly acknowledge the scientific input given by Shri K.V.S.A. Rao, Retired Chief Scientist, Centre for Lipid Research, CSIR-Indian Institute of Chemical Technology.

\section{REFERENCES}

AOCS. 2004a. Acid value. Cd 3d-63. In: Firestone D (ed) Official methods and recommended practices of the American Oil Chemists' society, 4th edn. American Oil Chemists' Society Press, Champaigne.

AOCS. 2004b. Saponification value. Cd 3-25. In: Firestone D (ed) Official methods and recommended practices of the
American Oil Chemists' society, 4th edn. American Oil Chemists' Society Press, Champaigne.

Berdeaux O, Christie WW, Gunstone FD, Sebedio JL. 1997. LargeScale Synthesis of Methyl cis-9,trans-11-Octadecadienoate from Methyl Ricinoleate. J. Am. Oil Chem. Soc. 74, 1011-1015. http://dx.doi.org/10.1007/s11746-997-0018-z.

Gamayurova VS, Zinoveva ME, Tran HTT. 2013. Features of the enzymatic hydrolysis of castor oil. Catalysis Indust. $\mathbf{5}$, 269-273. http://dx.doi.org/10.1134/S2070050413030045.

Goswami D, Basu JK, De S. 2013. Lipase applications in oil hydrolysis with a case study on castor oil: a review. Crit. Rev. Biotechnol. 33, 81-96. http://dx.doi.org/10.3109/0738 8551.2012.672319.

Goswami D, Sen R, Basu JK, De S. 2009a. Maximization of bioconversion of castor oil into ricinoleic acid by response surface methodology. Bioresour. Technol. 100, 4067-4073. http://dx.doi.org/10.1016/j.biortech.2008.11.040.

Goswami D, Basu JK, De S. 2009b. Optimization of process variables in castor oil hydrolysis by candida rugosa lipase with buffer as dispersion media. Biotechnol. Bioprocess Eng. 14, 220-224. http://dx.doi.org/10.1007/s12257-008-0123-3.

Knezevic ZD, Siler-Marinkovic SS, Mojovic LV. 1998. Kinetics of lipase-catalyzed hydrolysis of palm oil in lecithin/izooctane reversed micelles. Appl. Microbiol. Biotechnol. 49, 267-271. http://dx.doi.org/10.1007/s002530051167.

Kulkarni SR, Pandit AB. 2005. Enzymatic hydrolysis of castor oil: An approach for rate enhancement and enzyme economy. Indian J. Biotechnol. 4, 241-245.

Lakshminarayana G, Subbarao R, Sita Rama Sastry Y, Kale V, Chandrasekhara Rao T, Gangadhar A. 1984. High pressure splitting of castor oil. J. Am. Oil Chem. Soc. 61, 1204-1206. http://dx.doi.org/10.1007/BF02636251.

Neeharika TSVR, Lokesh P, Prasanna Rani KN, Prasad RBN. 2014. Optimization of Enzymatic Hydrolysis of Enriched Castor Oil Methyl Ester using Response Surface Methodology. J. Lipid Sci. Technol. 46, 8-14.

Patel BP, Patel HS, Patel SR. 2004. Modified castor oil as an epoxy resin curing agent. E-J Chem. 1, 11-16. http://dx.doi. org/10.1155/2004/412906.

Puthli MS, Rathod VK, Pandit AB. 2006. Enzymatic hydrolysis of castor oil: process intensification studies. Biochem. Eng. $J .31,31-41$. http://dx.doi.org/10.1016/j.bej.2006.05.017.

Rao KVSA, Paulose MM, Lakshminarayana G. 1990. In situ lipolysis of castor oil in homogenised castor seeds. Biotechnol. Lett. 12, 377-380. http://dx.doi.org/10.1007/ BF01024435.

Rao KVSA, Paulose MM. 1992. A process for splitting of castor oil at ambient temperature using homogenised castor seed as lipase source. Res. Ind. 37, 36-37.

Rao KVSA, Vijayalakshmi P, Prasad RBN. A process for the enrichment of methyl ricinoleate from castor oil methyl esters by liquid liquid extraction. Patent no. WO 2009/ 109985.

Rathod VK, Pandit AB. 2009. Effect of various additives on enzymatic hydrolysis of castor oil. Biochem. Eng. J. 47, 93-99. http://dx.doi.org/10.1016/j.bej.2009.07.008.

Sharon C, Nakazato M. Ogawa HI, Kato YM. 1999. Bioreactor operated production of lipase: castor oil hydrolysis using partially-purified lipase. Indian J. Exp. Biol. 37, 481-486.

Yamamoto K. Fujiwaran N. 1995. The hydrolysis of castor oil using a lipase from Pseudomonas sp. f-B-24: positional and substrate specificity of the enzyme and optimum reaction conditions. Biosci. Biotech. Biochem. 59, 1262-1266. http:// dx.doi.org/10.1271/bbb.59.1262.

Yang JW, Jeon GJ, Hur BK. 1999. Hydrolysis of castor oil with lipases and organic solvents. Korean J. Biotechnol. Bioeng. 14, 696-701. 